\title{
Impact of Industry Collaboration in Developing core Engineering Departments
}

\author{
D Pratibha ${ }^{1}, \mathrm{P}$ Anurag ${ }^{2}, \mathrm{C}$ Nagamani $^{3}$, D Sruthi keerthi ${ }^{4}$ \\ $1,2,3,{ }^{4}$ Anurag University, Venkatapur, Hyderabad, India. \\ ${ }^{1}$ pratibhamech@cvsr.ac.in, \\ 2apalla@anurag.edu.in
}

\begin{abstract}
Undergraduate education plays a vital role in the career path of any Individual, be it in professional or nonprofessional program. Specifically, Technical Education demands a balance of practical exposure with Theoretical knowledge acquired by the students. In the previous years, this type of education which enables the student to spend part of his graduation period in Industry is abysmal in India.
\end{abstract}

The system of Technical Education understands the role of Industry in a student growth in technical Education. In the present scenario of student centric learning where outcome based education is playing a vital role, Industry exposure will enable the students to understand the concepts he actually learns in classroom. This will help the institution to develop core engineering students.

This paper gives a detailed study on the impact of Industry collaborative activities in the institution. The Under graduate students who have performed these activities were impacted directly in the form of placements. The students are from core engineering stream like Electronics and Communications Engineering, Mechanical Engineering, Chemical Engineering and Electrical and Electronics Engineering. The students were involved in the activities like projects, internships and Industrial visits through the Industry Institute Interaction cell in the author's Institution. The paper shows the complete 3 year data and the impact of each activity in the core engineering departments thoroughly.

Keywords: Industry Institute Interaction, Engineering, Collaboration, Under Graduate education, Entrepreneurship.

\section{INTRODUCTION:}

With the impact of Digitalization and competencies around the world, the Indian Economy has opened up to outside World.

To cater to the Engineering problems and needs, the Industries consult Engineering Students/Institutions. The Need for Core Engineering jobs in Multinational Companies is high amongst engineering students.
These objectives can only be achieved well by bridging the gap between industry and the academic institutions. The need of the hour is better interaction between Engineering institutions and

industry. The association between the Institution and the Industry will have great impact on the engineering curriculum, exposure of engineering students to industrial atmosphere and subsequent placement of young graduate engineers in industries across the country.

Industries and institutes are collaborating since a very long period, but the rise of a global knowledge economy has intensified the need for strategic partnerships. The Institutes are providing the basic Technical knowledge and skill, but the Industry-Institute Interaction will enable to undertake research by staff and students relevant to the industry. This will empower students for having a sound technical exposure.

The Industry-Institute Interaction should be engaging students in the industry for a longer period for preparing the manpower of world class in the field of science and technology.

With several stages of collaboration being built by the government of India to develop the Make in India program, the need for the manpower have to be satisfied in order to witness the required development. Though availability of manpower is abundant in India, well skilled manpower with employability and equipped is the need of the hour.

There is a need for a close academia and industry interaction through all the phases of technology development, starting from conceptualizing to commercialization.

\section{NEED FOR INDUSTRY INSTITUTE INTERACTION:}

The vision of any Technical Institution is to produce equipped, skilled, globally employable professionals through a highly esteemed technical education and to prepare them for huge competition. Industries absorb these professionals and develop its production capabilities by contributing the latest technologies. 
To produce highly competent graduates ready for the industry, it is important to know the requirements and the technologies used in the industries through industry-institute interaction. Hence, a good and promising industry institute interaction to promote education and entrepreneurship is definitely required. To build good association between the industry and the institute, institutes should have Memorandum of Understanding (MoU) with the companies.

Industry-Institute Interaction (I-I-I) is the most sought after activity for mutual benefit and growth of industries as well as institutions. I-I-I offers the best platform for utilizing the best practices, latest technological advancements, and their implementation and impact in the industrial Development. Also, I-I-I promotes Technology gurus from the Industry to participate in curriculum design which plays a vital role in making the students employable. Through I-I-I, industries can contribute for technical education programs and cross-fertilize ideas for systems improvement. Many Academic Developing activities like Teaching-learning processes can be improved by integrating industrial training to both faculty and the students which also provides an exposure to the corporate world.

Students should be encouraged to undertake the mini/major projects in the industry with a joint guidance from the industry. I-I-I promotes development of entrepreneurship which further leads to rapid industrialization and hence improved economy of a country. I-I-I can also increase the R\&D activities in both, industries as well as institutions which further leads to the national growth and socio Economical Development.

\section{SKILL- GAP ANALYSIS:}

Technical education forms the backbone of development of any nation. The journey of collaboration between Industry and Institute has taken different routes and shapes at different times. Going back to history, it started with simple and formal interaction and eventually evolved to be a major key player in development of Academic Institutions with close partnership overtime. India is one of the largest producers of Technical Manpower, perhaps in the world. But compared to its population, there is still more scope for tremendous improvement in this area. Bridging the skill gap is the need of the hour and decides the national development and economic growth.

In the present generation students, as called Gen-Y students, the availability of electronic Gadgets around and free and abundant availability of network and internet services, the students do not feel the significance of learning real time applications of the concepts they learn during Engineering. The simulation is available all around and the students prefer simulation software than going for experimentation and practical exposure to latest equipment in the industry. Due to this, the students are lacking the knowledge and knowhow of any system working in
Industrial Environment. Systems implicate management system and also technical system.

This has become a regular concern from the Industrial heads that students lack the basic fundamental knowledge which is required for working in the shop floor. Without the exposure to the industry, the students take lot of time get accustomed to the safety rules and regulations, know the ethical standards etc in the industry.

To overcome these type of problems, Industry Interaction is necessary for developing the base for the fundamental knowledge of the students. This is enhance the capabilities, confidence levels and hence credibility of the student. Internship can be the best solution for such kind of issues. Students can involve in the production processes in the industry, know the ethical standards, follow safety standards during his tenure as an intern and then join as GET with fully ready for the job.

\section{OBJECTIVES OF SETTING UP INDUSTRY INSTITUTE INTERACTION CELL:}

- To nurture and train students to meet Industry requirements.

- To provide Internships in Industries in turn converted into placements.

- To encourage collaborative work for Product Development and Consultancy.

- To inculcate Industry Interaction through Guest Lectures, Industrial Visits and Training in cutting edge Technologies.

- To identify different avenues of industry-institute interaction.

- To study the role of industry in developing the faculty and students at the Institute level.

- To study the role of Institutes in building relations with the industry regarding manpower development and research.

- To suggest remedial measures to improve/enhance industry-institute interaction.

\section{IMPACT OF III IN THE FOLLOWING:}

Industry Institute Interaction impacts the Institutional activities involving both, Engineering students and faculty.

The career attributes include Entrepreneurship, Placements, R\&D, Consultancy works and Trainings for both faculty and students by the industry and vice versa.

1. Entrepreneurship

2. Curriculum

3. Project works

4. Internships

5. $\mathrm{R} \& \mathrm{D}$

6. Consultancy

7. Faculty Trainings 
8. Student trainings

9. Industrial employees training by the Academia

\subsection{Entrepreneurship:}

Corporate Entrepreneurship is important for organizational survival, profitability, growth, and renewal. The development of entrepreneurship amongst engineers will be an effective mechanism of luminous renaissance in technology innovations, helpful in the removal of regional discriminations and sustainable growth of SMEs. An engineer, through entrepreneurship as a future goal, can bring about a technical revolution that can meet the challenges of the emerging scenarios of globalization and liberalization, with a key element of competition. There are many strategies for developing entrepreneurial vision amongst engineers. There is a staunch necessity of the engineer to become an entrepreneur. The significance of industry/institute interaction in playing the role of engineering education resources and thus this impacts engineering education in the growth of small and medium enterprises.

The following is the sample activity chart made by the Entrepreneurship coordinator in the author's Institution. The coordinator conducted various programs spread widely through an academic year. These programs involve interactions between students and Industry experts. Rigorous Discussions on how to set up a "start up" " how to fund the project" to "problem Identification" is being dealt in these programs.

This helps the Institution to gain support from Industry. The students can have continuous guidance in setting up their firms.

Table 1- Activities done by ED-CELL in Author's Institution during 20192020

\begin{tabular}{|c|c|c|c|}
\hline S.No & Programme & $\begin{array}{l}\text { INDUSTRY } \\
\text { INVOLVE } \\
\text { D }\end{array}$ & Date \\
\hline 1 & $\begin{array}{l}\text { Orientation } \\
\text { Programme\& } \\
\text { Investiture }\end{array}$ & $\begin{array}{l}\text { Former } \\
\text { Student } \\
\text { Secretary, E } \\
\text { Cell } \\
\end{array}$ & $\begin{array}{l}\text { July } \\
2019\end{array}$ \\
\hline 2 & $\begin{array}{l}\text { Ideation Fest and Panel } \\
\text { Discussion } \\
\text { Entrepreneurship } \\
\text { Opportunities } \\
\text { Experiences }\end{array}$ & $\begin{array}{l}\text { Angel } \\
\text { Investor } \\
\text { Hamzek }\end{array}$ & $\begin{array}{l}\text { July } \\
2019\end{array}$ \\
\hline 3 & $\begin{array}{llll}\text { Paricipated } & & & \text { in } \\
\text { "Eximus" } & 3 & \text { day } & \text { E } \\
\text { summit } & \text { by } & \text { IIM } \\
\text { Bangalore } & & & \\
\end{array}$ & IIM B & $\begin{array}{l}\text { Aug } \\
2019\end{array}$ \\
\hline 4 & $\begin{array}{l}\text { Faculty Industry visit } \\
\text { to PalleSrujana }\end{array}$ & PalleSrujana & $\begin{array}{l}\text { Aug } \\
2019\end{array}$ \\
\hline 5 & $\begin{array}{l}\text { Skill development } \\
\text { workshop on Microart } \\
\text { by Dakshat Team }\end{array}$ & - & $\begin{array}{l}\text { Aug } \\
2019\end{array}$ \\
\hline 6 & $\begin{array}{l}\text { One day Workshop on } \\
\text { Entrepreneurship \& }\end{array}$ & $\begin{array}{l}\text { Coach- } \\
\text { Educator, }\end{array}$ & $\begin{array}{l}\text { Aug } \\
2019\end{array}$ \\
\hline
\end{tabular}

\begin{tabular}{|c|c|c|c|}
\hline & UI/UX & $\begin{array}{l}\text { Medicover } \\
\text { Hospitals } \\
\text { L\&T Metro } \\
\text { Rail } \\
\end{array}$ & \\
\hline 7 & Branch events & By students & $\begin{array}{l}\text { 1per } \\
\text { dept }\end{array}$ \\
\hline 8 & How to start a Startup & $\begin{array}{l}\text { Husys } \\
\text { Consulting } \\
\text { Ltd }\end{array}$ & $\begin{array}{l}\text { Sep } \\
2019\end{array}$ \\
\hline 9 & $\begin{array}{l}1 \text { Day Entrepreneur- } 50 \\
\text { Rs.exercise }\end{array}$ & $\begin{array}{l}\text { Student } \\
\text { business } \\
\text { game }\end{array}$ & $\begin{array}{l}\text { January } \\
2020\end{array}$ \\
\hline 10 & $\begin{array}{l}\text { VibhavanaHackathon } \\
\text { in collaboration with } \\
\text { JHUB }\end{array}$ & $\begin{array}{l}\text { Infosys } \\
\text { IBM }\end{array}$ & $\begin{array}{l}\text { Jan } \\
2020\end{array}$ \\
\hline 11 & $\begin{array}{l}\text { Start and Improve Your } \\
\text { Business (SIYB) in } \\
\text { collaboration with } \\
\text { CITD, MSME }\end{array}$ & MSME & $\begin{array}{l}\text { Feb, } \\
\text { Mar- } \\
2020\end{array}$ \\
\hline 12 & $\begin{array}{l}\text { Participated } \\
\text { PalleSrujanaChinnaSho } \\
\text { dayatra }\end{array}$ & $\begin{array}{l}\text { Village visit } \\
\text { for } \\
\text { identifying } \\
\text { rural } \\
\text { entrepreneur } \\
\text { s }\end{array}$ & $\begin{array}{l}\text { Feb- } \\
\text { Mar } \\
2020\end{array}$ \\
\hline 13 & $\begin{array}{l}\text { Wake up Call - 3day } \\
\text { webinars }\end{array}$ & $\begin{array}{l}\text { Digidine } \\
\text { Wave.com } \\
\text { Renodo } \\
\text { Job Thomas } \\
\end{array}$ & $\begin{array}{l}\text { July } \\
2020\end{array}$ \\
\hline 14 & 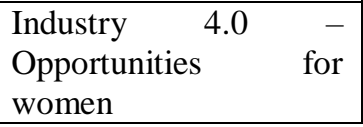 & ALEAP & $\begin{array}{l}\text { Sep } \\
2020\end{array}$ \\
\hline
\end{tabular}

5.2 Curriculum:

Industries and Institutes have been working together for over a longtime, but the rise of a global knowledge economy has been demanding for the need for outcome based partnerships. The Institutes are delivering the basic knowledge and skill, but the Industry-Institute-Interaction will enable to undertake research oriented technical projects/consultancies by staff and students relevant to the Industry. The Industry-Institute-Interaction should be designed to give long run outputs and must continue to contribute for a longer period for preparing the manpower which can be employable anywhere in the fields of science and technology by inculcating the various skills required by the industry and thereby contributing to the economical and socioeconomic development of the citizen of India at a large scale. Table 2: list of companies involved in Board Of Studies in core Engineering departments

\begin{tabular}{|c|c|c|}
\hline SI No & Department & $\begin{array}{l}\text { Companies involved in } \\
\text { Board Of Studies }\end{array}$ \\
\hline 1 & CSE & $\begin{array}{ll}\text { 1. } & \text { TCS } \\
\text { 2. } & \text { WAVELABS }\end{array}$ \\
\hline 2. & CIVIL & $\begin{array}{ll}1 . & \text { VARIJA } \\
& \text { PROJECTS } \\
2 . & \text { KIRBY }\end{array}$ \\
\hline
\end{tabular}




\begin{tabular}{|c|c|c|}
\hline 3. & CHEMICAL & $\begin{aligned} & \text { 1. } \text { HETERO } \\
& \text { DRUGS } \\
& 2 . \text { AUROBINDO } \\
& \text { PHARMA } \\
&\end{aligned}$ \\
\hline 4. & MECH & $\begin{array}{ll}\text { 1. } & \text { TECH } \\
& \text { MAHINDRA } \\
\text { 2. } & \text { CYIENT } \\
\end{array}$ \\
\hline 5. & ECE & $\begin{array}{ll}\text { 1. } & \text { AMS SEMI } \\
& \text { CONDUCTORS } \\
\text { 2. } & \text { INTEL } \\
\text { 3. } & \text { DELL } \\
\end{array}$ \\
\hline 6. & EEE & $\begin{array}{ll}\text { 1. } & \text { CAL-ON } \\
\text { 2. } & \text { SAPIENT } \\
& \text { SYSTEMS }\end{array}$ \\
\hline
\end{tabular}

\subsection{Project Works/Internships:}

The industry-institute collaboration is one of the major aspects which an engineering institution is currently concentrating. The aim of any institution is to create new avenue in educating Engineering graduates and providing fundamental education. The industry focuses on application oriented knowledge which can be transformed into better productivity. But the major challenge over here is employability for the graduates to transform their knowledge gathered into an application which has industrial need. Industry-Institute collaboration is not new concept, as we all know the world is being more competitive to remain sustained there is need for both industry-institute get involve into collaboration to encourage innovation and competitiveness in global economy.

Table 3: Internships data in the author's institution during 2019-20

\begin{tabular}{|l|c|c|c|c|c|c|}
\hline Number of & ME & EE & EC & CS & $\begin{array}{c}\text { CHE } \\
\text { M }\end{array}$ & CIV \\
\hline $\begin{array}{l}\text { Total } \\
\text { Internships }\end{array}$ & 46 & 15 & 33 & 50 & 40 & 11 \\
\hline $\begin{array}{l}\text { Paid } \\
\text { Internships }\end{array}$ & 35 & 15 & 20 & 30 & 0 & 0 \\
\hline $\begin{array}{l}\text { Unpaid } \\
\text { Internships }\end{array}$ & 11 & 0 & 13 & 20 & 40 & 11 \\
\hline $\begin{array}{l}\text { Average } \\
\text { Stipend } \\
\text { (INR) }\end{array}$ & $5 \mathrm{k}$ & $5 \mathrm{k}$ & $5 \mathrm{k}$ & $7.5 \mathrm{k}$ & 0 & 0 \\
\hline $\begin{array}{l}\text { Internships } \\
\text { likely to be } \\
\text { converted } \\
\text { to } \\
\text { Placement }\end{array}$ & 30 & 0 & 30 & 15 & 2 & 0 \\
\hline
\end{tabular}

A large number of educational institutes are coming to the opinion that internship programs are an excellent source for career and professional preparation of the students.
Table 4: details of the titles given to students during the allotment in the respective Industries

\begin{tabular}{|l|l|l|}
\hline $\begin{array}{l}\text { S. } \\
\text { No }\end{array}$ & $\begin{array}{l}\text { Technical Project Title given } \\
\text { to students }\end{array}$ & Company Name \\
\hline 1 & $\begin{array}{l}\text { Hermetically sealed rotary } \\
\text { compressor refrigeration and } \\
\text { air-conditioning }\end{array}$ & TECUMSEH \\
\hline 2 & $\begin{array}{l}\text { Analysis to reduce the rotor } \\
\text { run out rejection PPM }\end{array}$ & \\
\hline 3 & $\begin{array}{l}\text { Study on process of cold rolled } \\
\text { steel strips \& precision tubes }\end{array}$ & $\begin{array}{l}\text { PENNAR INDUSTRIES } \\
\text { LIMITED }\end{array}$ \\
\hline 4 & $\begin{array}{l}\text { Modeling and NC program } \\
\text { generation of mechanical PDU } \\
\text { boxes }\end{array}$ & $\begin{array}{l}\text { RAMTECH } \\
\text { MANUFACTURING } \\
\text { INDUSTRIES }\end{array}$ \\
\hline 5 & $\begin{array}{l}\text { Study of cigarette } \\
\text { manufacturing machine }\end{array}$ & $\begin{array}{l}\text { DYNAMIC TOOLS } \\
\text { PVT.LTD }\end{array}$ \\
\hline 6 & $\begin{array}{l}\text { Crawler drill JRD cd-110 } \\
\text { JUPITER ROCK } \\
\text { DRILLS(P) LIMITED }\end{array}$ \\
\hline 7 & $\begin{array}{l}\text { Heat treatment of drilled } \\
\text { cylindrical tubes }\end{array}$ & $\begin{array}{l}\text { SAI DEEPA ROCK } \\
\text { DRILLING TOOLS }\end{array}$ \\
\hline 8 & $\begin{array}{l}\text { Centrifugal crusher/ rotor } \\
\text { impact mill }\end{array}$ & $\begin{array}{l}\text { BHS SONTHOFEN } \\
\text { INDIA (P) LTD }\end{array}$ \\
\hline 10 & Design of 5kva ups box & $\begin{array}{l}\text { RC ALLTECH POWER } \\
\text { SYSTEMS PVT. LTD }\end{array}$ \\
\hline 11 & Study on drilling machines & $\begin{array}{l}\text { DYNATECH } \\
\text { INDUSTRIES }\end{array}$ \\
\hline 12 & V-belt manufacturing process & JK FENNER \\
\hline
\end{tabular}

They provide work-related experience to the students. On the other hand, they make it easy for the companies to select flexible, experienced and highly qualified job applicants. So internship programs are rewarding to the students, educational institutions and employers. This is the era of innovations and technological development and expansion. So it is necessary to grow such capabilities in the students that will assist them to deal with the modern world of work. For this, there is a need to reform the educational system of India by improving teaching methods, curriculum development, involving more research and providing practical training to the students. Internship programs create a link between classroom concepts and real workplace experience.

\subsection{R\&D and Consultancy Works:}

Technical Institutions, specifically Research centres in them, must be considered as future Entrepreneurs/Industries and organization, which provides solutions to various industrial task, research and problems. The Interaction should be in a stage where institutions as well as industries display the technological development and its effects on the industry.

Research institute partnership with industry can add the value of professional and technical education. Industries can contribute in professional and core Technical courses with the goal of interchanging thoughts for organizational growth by close cooperation with the institution. 
Interaction with industry is important to accommodate students in the internships and other training program to improve technical learning and teaching process. It helps students to gather and learn practical knowledge, expose to industrial atmosphere and acquire necessary skills; improves student alertness on job roles in the organization. The industrial requirements based on the technologies for the placement of students can be known by collaboration. Technology based Innovations, creativity and engineering determines global Competitiveness and productivity of any country.

Technical Institutions need to take awareness and information of the varying engineering problems and requirements of industries to develop new course and industry must recognize that sustenance for engineering institute is valuable. Big changes can happen if academic knowledge is paired with the technology experts in the industry. Industry academia collaboration can be emphasized to enhance research \& innovation, teaching \& learning, employability and knowledge transfer.

Motivation of Research Work Engineering institutes have collaborated to industries, it is very important to see this whether this collaboration is a win-win situation for both Institution and also industry in terms of research \& innovation, improvement in teaching and learning process, employability of student and success of knowledge transfer between industry and institutes.

Table 5: activity data of IIIC

\begin{tabular}{|l|l|l|l|l|}
\hline Activity & $\begin{array}{c}\mathbf{2 0 1 6 -} \\
\mathbf{1 7}\end{array}$ & $\begin{array}{c}\mathbf{2 0 1 7 -} \\
\mathbf{1 8}\end{array}$ & $\begin{array}{c}\mathbf{2 0 1 8} \\
\mathbf{1 9}\end{array}$ & $\begin{array}{c}\mathbf{2 0 1 9 -} \\
\mathbf{2 0}\end{array}$ \\
\hline Projects & - & 81 & 84 & 24 \\
\hline Internships & - & 312 & 408 & $656^{*}$ \\
\hline Placements & - & 04 & 207 & $62^{*}$ \\
\hline MOUs & 8 & 57 & 33 & 35 \\
\hline $\begin{array}{l}\text { Other } \\
\text { Activities(guest } \\
\text { lectures, } \\
\begin{array}{l}\text { Industries Visits } \\
\text { etc) }\end{array}\end{array}$ & - & 12 & 30 & 34 \\
\hline
\end{tabular}

\subsection{Placements:}

The Industry Institute collaboration is a medium to bridge the gap between Skill required in the industry and the knowledge of the student which he gains during his courses in B.Tech program. The Author show cases some feedback which is given by the students who were impacted directly from this association. The final year students in the author's Institution are sent to internship through a selection procedure according to their merit. Once the student completes the Internship, he is absorbed in the industry based on his performance. This is a win-win situation for both, Industry and student. The Industry will be able to assess the student's abilities one by one throughout his stay. This is done by paying him only Internship stipend. From the student's point of view, he gets time to prove his capabilities and learn many processes involved in the industry. So, this shows how a placement can be done in an organized way by collaborating with Industries.

The following are some of the feedback the author received after placing the students in core Engineering jobs through I-I-I:

Feedback 1:

Student name: TanayDubey.

Year of passing: 2019

Company placed: FMC Technologies

"Internship experience had helped me to actually witness and understand what companies want and the subjects that are used in practice in the industry. This internship helped me understand about high pressure conditions in machines, moving parts in machines and maintenance of all the different systems in a complex machine are crucial concepts that have helped me and continue to help me in my professional career. This was possible through Industry collaboration of our Institution"

Feedback 2:

Student Name: JonathJoby

Year of passing: 2019

Company placed: AmarRaja Group

The following is my experience with the I-I-I cell in the final year of my $B$ tech degree.

The I-I-I cell was extremely helpful throughout the placement process. They constantly thrived to bring in as many core companies as possible and guided me throughout the process. They constantly took feedback from the students regarding their interests and the kind of companies to go after. It was an enriching experience to work under the guidance of the I-I-I cell, especially during the interaction with Amara Raja group, where the whole hiring process was held in the college, and was carried out with exceptional efficiency and promptness. I was able to secure the placement. I would like to express my heartfelt thanks to the I-I-I cell for their continuous and thorough support in each and every phase of the placement process.

Feedback 3: 
Student name: K Shanshank.

Year of passing: 2020

Company placed: Rexnord

Industry institute interaction cell in Anurag University is a great platform to gain knowledge on the latest technological advancements through the exposure of industrial atmosphere to engineering students. Industrial visits and guest lectures by eminent persons from industries helped me in identifying the industry needs. Through this knowledge, I prepared myself to get ready for the industry. III gave me a lot of resources and opportunities to get placed as a design engineer.

Table 6: shows the companies which recruited final Year Mechanical Engineering students in the Year 2019-20

\begin{tabular}{|l|l|l|}
\hline $\begin{array}{l}\text { Name of the } \\
\text { Organization }\end{array}$ & $\begin{array}{l}\text { Number of } \\
\text { students placed }\end{array}$ & Package \\
\hline FMC & 01 & $6 \mathrm{LPA}$ \\
\hline Think-Notch & 03 & $4.5 \mathrm{LPA}$ \\
\hline AmaraRaja Group & 01 & $2.69 \mathrm{LPA}$ \\
\hline Avyayaya & 32 & $1.65 \mathrm{LPA}$ \\
\hline Isuzu & 03 & $1.4 \mathrm{LPA}$ \\
\hline KFORE & 06 & $1.65 \mathrm{LPA}$ \\
\hline
\end{tabular}

\subsection{Student/faculty trainings:}

Industries implement latest technologies and use most recent versions of any software required for their production. The equipment they use is also latest. Hence the students get to work in this fully equipped environment so as to get absorbed in the industry eventually.

Similarly, the trainings on the latest Technological in the Industry can be encouraged to be taken by to the faculty who can in turn deliver this knowledge to student. This can assure knowledge transfer to more number of students.

Three Day National Level Workshop Titled

\section{"Role of Industry and Academia in}

Building Institutions and Innovations"

During $28^{\text {th }}-30^{\text {th }}$ May 2020 for which there was a huge number of audiences. This was conducted in the month of May 2020. The sessions were purely online. Audience from all over India participated in this program. The resource persons were entirely from Industry sharing their insights on how an industry will contribute for the development of an Institution.

The following are the details:

Number of Resource persons-11
Number of sessions-11

Number of registrations- 505

Number of participants- 245

Table 7: data of companies involved in the workshop

\begin{tabular}{|c|c|c|}
\hline $\begin{array}{l}\text { Sl } \\
\text { no }\end{array}$ & $\begin{array}{l}\text { Company which } \\
\text { contributed }\end{array}$ & Title \\
\hline 1 & $\begin{array}{l}\text { VidhyaSangha } \\
\text { Technologies Pvt Ltd }\end{array}$ & $\begin{array}{l}\text { Equipping Students in } \\
\text { Latest Technologies to } \\
\text { suit Industries }\end{array}$ \\
\hline 2 & Signode & $\begin{array}{l}\text { Industrial Exposure to } \\
\text { Academia }\end{array}$ \\
\hline 3 & $\mathrm{ABB}$ & $\begin{array}{l}\text { Design and } \\
\text { Manufacturing } \\
\text { Industries Expectation } \\
\text { from Academia }\end{array}$ \\
\hline 4 & $\begin{array}{l}\text { Sri Venkateshwara } \\
\text { College of } \\
\text { Engineering, } \\
\text { Bengaluru }\end{array}$ & $\begin{array}{l}\text { Industry Institute } \\
\text { Collaborative Activities }\end{array}$ \\
\hline 5 & Smart Bridge & $\begin{array}{l}\text { Career readiness } \\
\text { framework for next } \\
\text { Gen Talent Pool }\end{array}$ \\
\hline 6 & $\begin{array}{l}\text { DCM-Sriram } \quad \text { Bio } \\
\text { Seed Pvt Ltd }\end{array}$ & $\begin{array}{l}\text { Industry Expectations } \\
\text { and Contributions from } \\
\text { Academia }\end{array}$ \\
\hline 7 & TVS & $\begin{array}{l}\text { Scope of Engineers in } \\
\text { Manufacturing } \\
\text { Industries }\end{array}$ \\
\hline 8 & Eride & $\begin{array}{l}\text { Scopes and Market } \\
\text { potential in EV Sector }\end{array}$ \\
\hline 9 & DELL & $\begin{array}{l}\text { Usage and Adaption of } \\
\text { novel Technologies in } \\
\text { Industries }\end{array}$ \\
\hline 10 & MIC Electronics & $\begin{array}{l}\text { Career opportunities to } \\
\text { Core } \\
\text { Students }\end{array}$ \\
\hline
\end{tabular}




\begin{tabular}{|l|l|l|}
\hline 11 & $\begin{array}{l}\text { HPL Power and } \\
\text { Electric ltd }\end{array}$ & $\begin{array}{l}\text { Scope of Engineers in } \\
\text { Smart Metering as a } \\
\text { Start-Up }\end{array}$ \\
\hline
\end{tabular}

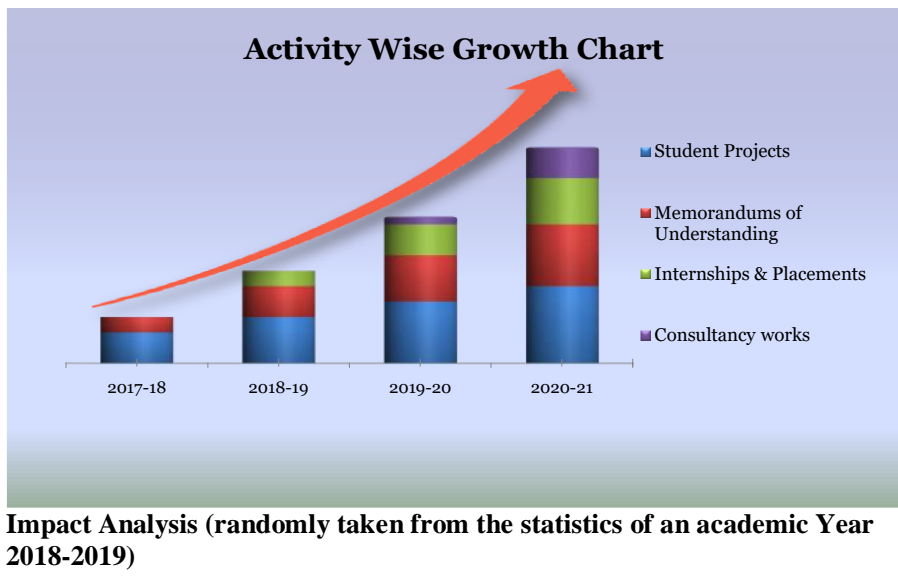

\section{HOW AN INSTITUTION CAN ATTAIN GREATER AVENUES BY IIIC:}

- By designing credit based programs which involve exposure to Industry by Project/Internships/field trips.

- By Deputing faculty for training industry personnel in the required Subjects/courses.

- $\quad$ By inviting Guests from Industries to lecture on Latest and Emerging Technologies for bringing awareness in students

- By conducting faculty Skilling programs which include resource persons from Industries

- By counseling the present generation of students, the importance of having practical exposure to the concepts they learn during their B.Tech program

\section{BENEFITS OF I-I-I:}

- Industry institute interactions go beyond academics and it is excellent exposure for students to attain practical perspective of the world of work.

- Students get an opportunity to learn practically by applying their theoretical knowledge, through working methods, interactions and employment practices.

Table8: Benefits of Institute Industry Interaction

\begin{tabular}{|l|l|l|l|}
\hline $\begin{array}{l}\text { SI } \\
\text { no }\end{array}$ & $\begin{array}{l}\text { Benefits for } \\
\text { the } \\
\text { Institution }\end{array}$ & $\begin{array}{l}\text { Benefits for } \\
\text { the Industry }\end{array}$ & $\begin{array}{l}\text { Benefits for the } \\
\text { students }\end{array}$ \\
\hline 1 & $\begin{array}{l}\text { Easy access } \\
\text { to latest } \\
\text { technologies, } \\
\text { Equipments }\end{array}$ & $\begin{array}{l}\text { Easy } \\
\text { recruitment }\end{array}$ & $\begin{array}{l}\text { Gaining real } \\
\text { time application } \\
\text { exposure. }\end{array}$ \\
\hline 2 & Opportunity & A highly & Application of \\
\hline
\end{tabular}

\begin{tabular}{|c|c|c|c|}
\hline & $\begin{array}{l}\text { to attract } \\
\text { additional } \\
\text { funds for } \\
\text { teaching and } \\
\text { research } \\
\text { through } \\
\text { R\&D, } \\
\text { consultancy, } \\
\text { testing and } \\
\text { inspection. }\end{array}$ & $\begin{array}{l}\text { committed and } \\
\text { devoted think- } \\
\text { tank availability }\end{array}$ & $\begin{array}{l}\text { theoretical } \\
\text { concepts in } \\
\text { Industrial } \\
\text { Environment }\end{array}$ \\
\hline 3 & $\begin{array}{l}\text { Development } \\
\text { and } \\
\text { adaptation of } \\
\text { need based } \\
\text { curriculum }\end{array}$ & $\begin{array}{l}\text { A detailed } \\
\text { assessment of } \\
\text { the student }\end{array}$ & $\begin{array}{l}\text { Contact with } \\
\text { practicing } \\
\text { professionals }\end{array}$ \\
\hline 4 & $\begin{array}{l}\text { Improved } \\
\text { employment } \\
\text { prospects for } \\
\text { students. }\end{array}$ & $\begin{array}{l}\text { Cost effective } \\
\text { productivity. }\end{array}$ & $\begin{array}{l}\text { Availability of } \\
\text { time to make } \\
\text { Decision on } \\
\text { career choice }\end{array}$ \\
\hline 5 & $\begin{array}{l}\text { Socially } \\
\text { relevant and } \\
\text { progressive } \\
\text { education }\end{array}$ & $\begin{array}{l}\text { Collaborative } \\
\text { research } \\
\text { opportunities. }\end{array}$ & $\begin{array}{l}\text { An opportunity } \\
\text { to access to } \\
\text { instruments, } \\
\text { latest equipment } \\
\text { and emerging } \\
\text { technologies. }\end{array}$ \\
\hline 6 & $\begin{array}{l}\text { Enhancement } \\
\text { of the } \\
\text { institution's } \\
\text { image as a } \\
\text { contributor to } \\
\text { the Country's } \\
\text { Economy and } \\
\text { Best } \\
\text { producers of } \\
\text { Technical } \\
\text { Graduates }\end{array}$ & $\begin{array}{l}\text { Communication } \\
\text { with Academic } \\
\text { and highly } \\
\text { knowledgeable } \\
\text { experts. }\end{array}$ & $\begin{array}{l}\text { Understanding } \\
\text { the work } \\
\text { atmosphere and } \\
\text { culture, ethics } \\
\text { and safety } \\
\text { responsibilities } \\
\text { of the industry. }\end{array}$ \\
\hline 7 & $\begin{array}{ll}\text { Provide } & \\
\text { industrial } & \\
\text { training } & \text { to } \\
\text { students } & \& \\
\text { Staff } & \end{array}$ & $\begin{array}{l}\text { Quality, Testing } \\
\& \text { Inspection } \\
\text { facilities }\end{array}$ & $\begin{array}{l}\text { Paid pre- } \\
\text { employment }\end{array}$ \\
\hline
\end{tabular}

\section{Conclusion}

- Industry Institution Interaction is the future of any Technical Educational Institution. It is going to play a key role in giving most anticipated outcome.

- The managements are realizing the importance of the Associations and encouraging the Industry to set up Centers of Excellence in most emerging Technologies.

- The Industries unlike before, are now emphasizing on Academia involvement in bringing new and cutting edge technologies and products. Also to train their personnel in these. 
- Students are smarter in choosing what the area they wish to work in and this advantage is given by core Industry recruitment happening in the institutions.

\section{Acknowledgements:}

- The authors would like to acknowledge the Management of Anurag University for giving an opportunity to interact with the industry and associate with them through Memorandum Of Understanding.

- The authors take this platform to thank the entire Industrial community in and around Hyderabad for providing an opportunity to the students of Anurag University to work in their respective firms and help improve their organization in all aspects.

- The authors finally thank the ICTIEE-2021 to give an opportunity to exhibit the work they are doing since 4 years to improve Institution placements through I-I-Icell.

\section{References:}

1. Ramaswamy, C., \&Brahadeeswaran, D. (2013). ESTABLISHING SUSTAINABLE INDUSTRY INSTITUTE PARTNERSHIPS- CASE STUDY OF AN ENGINEERING COLLEGE.

2. Xias, F., \&Jin, W. (2012). On the Factors that Affect the Proneness of University- Industry Cooperation: A System Engineering Perspective. Systems Engineering Procedia, 3, 275-281. https://doi.org/https://doi.org/10.1016/j.sepro.2011.11. 030

3. Siegel, D. S., Waldman, D. A., Atwater, L. E., \& Link, A. N. (2003). Commercial knowledge transfers from universities to firms: improving the effectiveness of university-industry collaboration. The Journal of High Technology Management Research, 14(1), 111-133. https://doi.org/10.1016/S1047-8310(03)00007-5

4. NAE. (2005). Educating the Engineer for 2020: Adapting Engineering Education to the New Century. Retrieved from www.nap.edu

5. Salleh, M. S., \& Omar, M. Z. (2013). Universityindustry Collaboration Models in Malaysia. Procedia Social and Behavioral Sciences, 102, 654-664. https://doi.org/10.1016/j.sbspro.2013.10.784

6. Şendoğdu, A. A., \&Diken, A. (2013). A Research on the Problems Encountered in the Collaboration between University and Industry. Procedia - Social and Behavioral Sciences, 99, 966-975. https://doi.org/10.1016/j.sbspro.2013.10.570

7. Rama Mohan, S., \& Ramakrishna Rao, A. (2005). Strategy for technology development in public R\&D institutes by partnering with the industry.
Technovation, 25(12), 1484-1491. https://doi.org/10.1016/j.technovation.2005.05.007

8. Santoro, M. D., \& Betts, S. C. (2002). MAKING INDUSTRY - UNIVERSITY PARTNERSHIPS WORK. 42-46.

9. Hagedoorn, B. J., Link, A. N., Vonortas, N. S., \& April, N. S. (2000). Research partnerships. By: John Hagedoorn, Albert $N$ Link and Nicholas $S$ VonortasHagedoorn, J., Link, A. N., \&Vonortas, N.S. (April 01, 2000). Research partnerships.29, 567-586.

10. Levy, R., Roux, P., \& Wolff, S. (2009). An analysis of science-industry collaborative patterns in a large European University. Journal of Technology Transfer, 34(1), 1-23. https://doi.org/10.1007/s10961-007-90440

11. Arvanitis, S., Kubli, U., \&Woerter, M. (2008). University-industry knowledge and technology transfer in Switzerland: What university scientists think about co-operation with private enterprises. Research Policy, 37(10), 1865-1883. https://doi.org/10.1016/j.respol.2008.07.005

12. D'Este, P., \& Patel, P. (2007). University-industry linkages in the UK: What are the factors underlying the variety of interactions with industry? Research Policy, 36(9), 1295-1313. https://doi.org/10.1016/j.respol.2007.05.002

13. Barnes, T., Pashby, I., \& Gibbons, A. (2002). Effective University - Industry Interaction:: A Multi-case Evaluation of Collaborative R\&D Projects. European Management Journal, 20(3), 272-285. https://doi.org/10.1016/S0263-2373(02)00044-0

14. BodasFreitas, I. M., Marques, R. A., \& de Paula e Silva, E. M. (2013). University-industry collaboration and innovation in emergent and mature industries in new industrialized countries. Research Policy, 42(2), 443-453. https://doi.org/10.1016/j.respol.2012.06.006

15. Meyer-Krahmer, F., \&Schmoch, U. (1998). Sciencebased technologies: university-industry interactions in four fields. Research Policy, 27(8), 835-851. https://doi.org/10.1016/S0048-7333(98)00094-8

16. Systems, I., Management, Q., \& Study, A. E. (2011). Journal of Technology Management for Growing Economies. 2(1).

17. Kumar, S., Luthra, S., \&Haleem, A. (2016). Critical Factors Important for Effective Industry- Institute Interactions (Iii): an Indian Perspective. International Journal of the Analytic Hierarchy Process, 8(1), 1-38. https://doi.org/10.13033/ijahp.v8i1.319

18. Kaufmann, A., \&Tödtling, F. (2001). Science-industry interaction in the process of innovation: the importance of boundary-crossing between systems. Research Policy, 30(5), 791-804. https://doi.org/10.1016/S0048-7333(00)00118-9

19. Adams, A. V. (2012). The Role of Skills Development in Overcoming Social Disadvantage. Background Paper Prepared for Education for All Global Monitoring Report 2012, 1-19. 
20. Sigroha, A., \&Chahal, A. (2013). Industry- Institute Interaction: Searching New Horizons. 01(02), 1-9.

21. NASSCOM. (2018). Annual Report 2018-19 Catalysing IT-BPM Industry in India. 112.

22. Industry institute interaction cell. (2016).

23. Industry - Institute Interaction In Modern Area. (2013). II(Ii).

24. (GMAC), G. M. A. C. (2012). Global Management Education Graduate Survey. The Gmac Survey Series.

25. International, T., \& Of, J. (2014). THE INTERNATIONAL JOURNAL OF BUSINESS \& MANAGEMENT A Study on the Significant Influence of Industry Institute Collaboration on Various Factors in Engineering Institutes in Pune Region. 2(6), 11-20. https://doi.org/10.13140/2.1.5054.0166

26. Nesta. (2010). Annual Innovation Report 2010. Innovation, (November), 1-37.

27. Graf, C., Hochleitner, C., Wolkerstorfer, P., Angulo, J., Fischer-hübner, S., Wästlund, E., \&Leenes, R. (2011). Final HCI Research Report Editors. (May).

28. Education, O. N. H., \& Issue, T. (2013). HIGHER EDUCATION GOVERNMENT OF INDIA HRM Inaugurates Conference on Theme-Based Innovation Institutes Campus Notes Editorial Panel Patron Editor-in-Chief. (1), 1-12.

29. Eppinger, S. D. (2010). MIT Sloan Management Review - how sustainability fuels design Innovation.

30. Majumdar,\&Shyamal. (2009). Industry-institute interaction to public-private partnership: a journey to excellence. $\quad$ Retrieved from http://hdl.voced.edu.au/10707/52865.

31. Kumar, S., \&Raghavan, V. (2008). Building a low carbon Indian Economy.

32. Miller, L. (2012). ASTD 2012 State of the Industry Report: Organizations Continue to Invest in Workplace Learning.

33. National Skill development programme annual report 2012. (2012).

34. Guerrero, M., Cunningham, J. A., \&Urbano, D. (2015). Economic impact of entrepreneurial universities' activities: An exploratory study of the United Kingdom. Research Policy, 44(3), 748-764. https://doi.org/10.1016/j.respol.2014.10.008

35. Szirmai, A., Naude, W., \&Goedhuys, M. (2011). Entreprenuership, Innovation, and Economic Deverlopment.

36. Padma, M. C., \& Sridhar, V. (2015). Role of IndustryInstitute Interaction to Promote Education and
Entrepreneurship. In R. Natarajan (Ed.), Proceedings of the International Conference on Transformations in Engineering Education (pp. 595-596). New Delhi: Springer India.

37. pdfToThesis @ sg.inflibnet.ac.in. (n.d.). Retrieved from

https://sg.inflibnet.ac.in/bitstream/10603/151646/15/13 _chapter 3.pdf

38. Industry-Institute-Interaction @ www.ictacademy.in. (n.d.). Retrieved from http://www.ictacademy.in/Pages/Industry-InstituteInteraction.aspx

39. Wallin, J., Isaksson, O., Larsson, A., \&Elfström, B. O. (2014). Bridging the gap between university and industry: Three mechanisms for innovation efficiency. International Journal of Innovation and Technology Management, 11(1), 1-18. https://doi.org/10.1142/S0219877014400057

40. Shettar, A., Desai, B. L., Iyer, N. C., Uma, K. M., Raju, A. B., Kerur, C. D., ... Joseph, A. (2015). An Effective Industry Institute Engagement for Curriculum Design and Delivery: A Success Story. Journal of Engineering Education Transformations, 29(1), 85. https://doi.org/10.16920/jeet/2015/v29i1/77124

41. Anilkumar, N., Jyoti, B., Kuashik, M., \&Shirol, S. (2015). Industry-Institute Interaction: An Important Step towards Empowering Skills of Engineering Students. Journal of Engineering Education Transformations, 29(1), 103. https://doi.org/10.16920/jeet/2015/v29i1/77145

42. Pittaway, L., \& Cope, J. (2007). Entrepreneurship education: A systematic review of the evidence. International Small Business Journal, 25(5), 479-510. https://doi.org/10.1177/0266242607080656

43. Bhat, S. (2013). A critical analysis of Industry Institute Interaction with Special Reference to management Institutes in pune District (Smt. HirabenNanavati Institute of Management).

44. Report on INDUSTRY INSTITUTE INTERACTION CELL ( IIIC) Sinhgad Technical Education Society' $s$ Sinhgad Academy of Engineering , Kondhwa, Pune. (2016). (Iiic), 2015-2016.

45. Pai, A. R., Rao, P. K., \& Learning, P. (2016). Role of Industry Institute Interaction in Making of Entrepreneurs. I(I), 357-361 